\title{
THE MEDICAL PRACTITIONERS OF PROVINCIAL ENGLAND IN 1783
}

\author{
by
}

JOAN LANE*

The Editors, who are influenced by no other motive than a desire of testifying their zeal and respect for their profession, have been anxiously careful, in the course of their work, to avoid giving cause of disgust to any individual, or to any body of men. (S. F. Simmons, Preface to the first edition of the Medical Register, 1779.)

Two hundred years ago, in September 1783, a London physician, Samuel Foart Simmons, published the third edition of his Medical Register, ${ }^{1}$ an ambitious venture that began in April 1779, with his first attempt to list the qualified medical practitioners in Britain, her colonies, and much of Europe. However, this first edition suffered from substantial omissions, largely due to the failure of Simmons's correspondents to answer his questions by post, pithily noted by him in footnotes for parts of Surrey, of Lincolnshire, and in Norwich, for example. ${ }^{2}$ These omissions were made good by the 1783 edition, so presumably his tart comments were effective. Four years and one more edition later, in 1783, his Register had expanded very considerably in the sheer number of names but with fewer details about the individual practitioners, their publications, and the county hospitals established in the provinces. The 1783 edition, however, is an impressive work, arranged geographically by British counties. There are separate sections on the Royal Colleges of Physicians, the Corporation and Royal College of Surgeons, and the Society of Apothecaries, as well as details of contemporary medical societies and local scientific and learned bodies. The English provincial practitioners can be found scattered among these various lists as well as included in their own county directory. Thus much interesting data is obscured for modern researchers, since although Simmons provided a cumulative name index, as well as lists of deaths and an appendix of amendments, there is erratic cross-referencing and some names slip through unnoticed altogether. In 1779, Simmons made no attempt, with far fewer names, to provide an index, but by 1783 his new publisher, Joseph Johnson, undertook to supply the index and defray its cost. Simmons admitted that an index had been a "desideratum in the former Editions, which the Editors, from the apparent Laboriousness of the Undertaking, had been deterred from supplying". He added a comment in praise of the indexer, who had "executed it with a Degree of Accuracy which cannot fail to please the Purchasers of the Work". The purpose of this survey is to look in some detail at the English 7AL.

*Joan Lane, MA, PhD, Centre for the Study of Social History, University of Warwick, Coventry CV4

Individual page references to Simmons's 1779 and 1783 Registers have not been cited, but all other sources are given.

${ }^{1}$ Samuel Foart Simmons, The Medical Register for the year 1783, London, Joseph Johnson, 1783.

${ }^{2}$ Samuel Foart Simmons, The Medical Register for the year 1779, London, J. Murray, 1779. 
provincial medical practitioners of 1783 , omitting military and naval appointees as well as men practising in London ${ }^{3}$ and Scotland, who have already been subjects of detailed inquiries. Wales was either too sparsely provided with medical practitioners in the 1783 Register (only eight physicians and 121 surgeon-apothecaries for the whole Principality) or Simmons's lists were incomplete for a similar analysis to be considered.

No attempt has been made to estimate the numbers of patients whom the 1783 practitioners attended, since before the first national census of 1801 population figures were erratically recorded, frequently using different criteria according to the purpose of the survey, for example, whether to assess the poor, the militia, the communicants in a parish, or the inhabitants on a great estate. Such population listings as were made only haphazardly coincided with the Medical Register of 1783 and most practitioners had patients from a far wider area than their own urban or rural community. Thus, though there were twenty practitioners listed in 1783 for Birmingham, whose population two years later was $52,250,{ }^{4}$ these men saw patients from beyond the town as well as those from the rest of the county who attended the new hospital there. Similar circumstances can be seen in other areas.

In 1783, there were just over 3000 civilian medical practitioners in provincial England; Simmons grouped them in several categories, listing physicians, surgeonapothecaries, surgeons, and apothecaries, as well as noting those men who practised a mixture of skills and those who engaged in midwifery work. As the Register was to list the qualified practitioners, the barber-surgeons, separated from the surgeons forty years earlier, were rigorously excluded, as were, of course, all fringe practitioners. The majority of men in the Register were surgeon-apothecaries (82.3 per cent) engaged in single-handed practice in the cities, market-towns, industrial centres, and larger villages, frequently with surgeries sited conveniently for the major roads of the area, enabling the practitioner to attend patients many miles away (Table 1). In addition, there were 363 physicians, with the qualification of MD or MB, but occasionally men with an Oxford or Cambridge MA, including clerics who also practised medicine. The physicians differed in every respect from the surgeon-apothecaries; as university men, entitled to be called "Doctor", untainted by the "manual" aspects of surgery, midwifery, or pharmacy, they provided professional advice for fees to patients who were usually the more prosperous members of their communities. Their distribution pattern, as recorded in 1783, emphasizes their exclusivity and, as they were relatively few in number and Simmons provided details about them individually, it is possible to trace their movements from one area to another, presumably to take advantage of enhanced opportunities for practice. As Simmons noted the university and date at which physicians obtained their qualifications, for the majority of physicians listed it is also possible to assess which medical schools were favoured, how long such men had been in practice, their ages, at what stage in their careers they held hospital or dispensary posts, and to discern whether there were some kind of network of

\footnotetext{
${ }^{3}$ W. F. Bynum, 'Physicians, hospitals and career structures in eighteenth-century London', in W. F. Bynum and R. S. Porter (editors), William Hunter and the medical world of the Enlightenment, Cambridge University Press, 1985 [in press].

‘Victoria County History, Warwickshire, Oxford University Press, 1964, VII, p. 8.
} 
relationships between, for example, men who had trained together. Simmons also included men who had retired from practice and a list of recently deceased practitioners.

TABLE 1: PROVINCIAL MEDICAL PRACTITIONERS IN ENGLAND IN 1783

\begin{tabular}{|c|c|c|c|c|}
\hline county & $\begin{array}{c}\text { surgeon- } \\
\text { apothecaries }\end{array}$ & physicians & $\begin{array}{l}\text { surgeons } \\
\text { only }\end{array}$ & $\begin{array}{c}\text { apothecarles } \\
\text { only }\end{array}$ \\
\hline Bedfordshire & 17 & 2 & & \\
\hline Berkshire & 44 & $11(2)$ & 1 & \\
\hline Buckinghamshire & 27 & 3 & & \\
\hline Cambridgeshire* & 20 & 3 & 4 & \\
\hline Cheshire* & 48 & 5 & 5 & 1 \\
\hline Cornwall & 71 & 6 & & \\
\hline Cumberland & 60 & $11(1)$ & & \\
\hline Derbyshire & 35 & 6 & & \\
\hline Devonshire* & 117 & 11 & $8(1)$ & 17 \\
\hline Dorset & 59 & 9 & 1 & \\
\hline Durham & 52 & 8 & & \\
\hline Essex & 112 & $13(1)$ & & \\
\hline Gloucestershire* & 60 & 6 & 2 & \\
\hline Hampshire* & 86 & 6 & & \\
\hline Herefordshire* & 33 & 5 & 3 & 1 \\
\hline Hertfordshire & 37 & 7 & & \\
\hline Huntingdonshire & 17 & 4 & & \\
\hline Kent & $161(1)$ & $12(1)$ & & \\
\hline Lancashire** & 102 & 26 & $14(1)$ & 6 \\
\hline Leicestershire* & 43 & 6 & & \\
\hline Lincolnshire* & 94 & 18 & 1 & 2 \\
\hline Middlesex & 68 & 3 & & \\
\hline Norfolk* & 129 & 14 & 1 & 1 \\
\hline Northamptonshire* & 46 & 9 & 1 & \\
\hline Northumberland* & 66 & 13 & & 2 \\
\hline Nottinghamshire* & 38 & 5 & & \\
\hline Oxfordshire* & 54 & 9 & 4 & 1 \\
\hline Rutland & 5 & 1 & & \\
\hline Shropshire* & 84 & 4 & & 1 \\
\hline Somerset*** & 93 & 29 & 18 & $\begin{array}{c}53 \text { [ }+2 \text { men- } \\
\text { midwives }]\end{array}$ \\
\hline Staffordshire* & 70 & 7 & & 1 \\
\hline Suffolk & $70(1)$ & 10 & 2 & \\
\hline Surrey & 63 & 8 & & \\
\hline Sussex & 81 & 5 & 3 & 3 \\
\hline Warwickshire* & 54 & 9 & 10 & 4 \\
\hline Westmorland & 13 & 2 & & \\
\hline Wiltshire* & 78 & 9 & 3 & 1 \\
\hline Worcestershire* & 67 & 5 & & \\
\hline Yorkshire*** & 233 & 42 & 8 & 11 \\
\hline totals & 2607 & 363 & 89 & $105+2$ \\
\hline percentage & 82.3 & 11.4 & 2.8 & 3.3 \\
\hline
\end{tabular}


The smallest categories of practitioners listed by Simmons were the eighty-nine who practised solely as surgeons and the 105 apothecaries; predictably, the majority were to be found in contemporary medical institutions, but in Somerset, Bath and Bristol were a striking exception to this, with substantial numbers of pure surgeons and pure apothecaries far in excess of hospital posts. ${ }^{5}$ The rarest category of all in the Register was that of man-midwife, with only two men so described, but with two more physicians also claiming to be accoucheurs. Such numbers are clearly an underestimate when compared with area trade directories of the period, perhaps because practitioners did not wish to inform Simmons of this aspect of their practice for inclusion in a national list but wanted to attract patients in a purely local directory. It is noticeable that the term, "surgeon, apothecary, man-midwife", so common in other contemporary material, is never used by Simmons, perhaps because obstetric practice was widely accepted as part of the surgeon-apothecary's regular work and the menmidwives listed as such by Simmons had, in fact, an exclusively female clientele and accepted difficult confinements referred to them.

Apart from the different categories of practitioners listed geographically in the English provinces (Table 1), Simmons also included names of men in the Society of Apothecaries and in the Surgeons' Company who were omitted from his county lists. In 1783, there were twenty-six apothecaries and forty surgeons in this group for whom a place of residence was given in the provinces; others were London men or had no place of residence named. These lists also provided the Christian names of thirty surgeons and five apothecaries, with their places of residence, making possible more accurate identification of men already in the county lists. Perhaps some of these men were retired; others did not engage in general practice. Such a man was James Butler, apprenticed in 1744 with an $£ 80$ premium to an Atherstone (Warwicks.) practitioner, Edmund Seager (MD, St. Andrews), one of the handful of men who was a physician also practising surgery and pharmacy. ${ }^{6}$ In 1773 , in his mid-forties, Butler was appointed as a personal medical attendant to the fifth Lord Leigh of Stoneleigh Abbey in Warwickshire, for whom a Commission in Lunacy had been obtained after a period of treatment from the leading "mad doctors", Willis and Monro. Payments to Butler began in December 1773, the date of the Commission." By 1779, Butler was ninth in seniority among the provincial surgeons, and by 1790 , he had risen to second place in the order. His patient, Lord Leigh, remained at the abbey under restraint for thirteen years, until his death in 1786. Butler was still a member of the Surgeons' Company in 1799, the last year for which a list was made, but he may have died at the turn of the century, for his name does not appear in the 1805 list of the Royal College of Surgeons. ${ }^{8}$ Also residing in a country house, according to Simmons's Register, was Timothy Markham, a yeomanry member of the Society of Apothecaries; in 1779, he was nineteenth in seniority and in 1783, he was eleventh when his address was The

5 PP, 1834 (XIII), part 2, Report from the Select Committee on the Education and Practice of the Medical Profession in the United Kingdom, p. 3. Guthrie considered that there were only 200 "pure surgeons who practised in the whole country and not quite so many in London" by the 1830s.

6 Public Record Office [PRO], I.R.1/50.

'Shakespeare Birthplace Trust Records Office, Stratford-upon-Avon, DR 18/31/461.

' Records of the Surgeons' Company of London: lists of members. 


\section{The medical practitioners of provincial England in 1783}

Weare, Herefordshire, one of the county's fine minor country houses. ${ }^{9}$ Markham's role within the household was, however, very different from Butler's, for some twenty years earlier, Markham had married a wealthy heiress, Elizabeth Smyth, and was responsible for much of the extensive rebuilding there in the 1780s, so his exercise of the apothecary's skills was presumably restricted to his own circle.

Although the 1783 Register had fewer personal entries about practitioners, a number of men have details recorded about their careers or backgrounds, especially if they came from medical families. Such information was quite randomly entered and depended presumably upon the personal knowledge of Simmons's local correspondents, but it is nevertheless valuable. Medical practitioners with interests beyond practice, such as running a private madhouse, a botanical garden, or the various local scientific societies that flourished in the late eighteenth century, often found a flattering footnote about their activities at the bottom of the appropriate page. Although the 1783 Register did not contain entries about practitioners' dissertations and publications on medical topics, Simmons occasionally noted other publications, so that, for example, William Pryce.(MD, St Andrews, 1781), who lived at Redruth, had a six-line footnote about his forthcoming book on the ancient Cornish language, whose "price to subscribers will be $£ 15 \mathrm{~s}$ ", while the catalogue to John Blackburne's botanic garden at Orford Hall, near Warrington, was worthy of a favourable footnote comment.

Simmons also included information about provincial hospitals and dispensaries in the Register, always listing the medical staff but in some cases adding details about the numbers of patients, size of wards, and ventilation methods. In the 1779 edition, he had noted by means of an asterisk and footnote those counties, such as Essex or Dorset, that lacked a county infirmary, but by 1783 , when only eighteen counties did not have a hospital or plans for one, he had ceased to do so. Simmons also added comments about proposals for building hospitals in 1783, noting with an approving footnote that in establishing Nottingham's general hospital in 1781, the support of the Mayor and Sheriffs in the town was an example for other corporations to follow. He mentioned that in 1783, both at Hull and at Taunton, hospitals were currently being built, while at Hereford, an extension to the main building was proposed for the reception of lunatics. Provincial dispensaries were far less common, but Simmons noted the eight that existed, their medical attendants, and numbers of patients, as well as the Newbury dispensary that had survived for only a year or two.

The growing network of hospitals in the provinces in the late eighteenth century, thriving or emerging, gives an interesting picture of the professional mobility of medical practitioners, especially if they were working in a community already too well provided with physicians but with a fairly static population. Thus James Hardy (MD, Aberdeen) had been one of three physicians in Barnstaple. The author of a study (1778) comparing the colic of Poitou with that of Devon, he left the West Country for the Midlands, where he served as one of the physicians at Northampton general hospital for four years. Similarly, John Storer (MD, Glasgow, 1771), also one of the

\footnotetext{
- The Weir was acquired by the National Trust in 1959, but only the gardens are open to the public; guide-books and other literature cite its date as 1784 . Humphry Repton was presumably consulted about the landscaping there, since he included a vignette of the house in Peacock's polite repository, 1799, V.
} 


\section{Joan Lane}

three physicians at Grantham in the year 1783, moved to be the most junior of the three physicians at the new Nottingham hospital. There he established a local reputation in the county and attended a wide range of patients until well into the nineteenth century. ${ }^{10}$ Even a hospital only partly complete in 1783 attracted ambitious young men to change their practice area. In 1777, Stanhope Bayne gained his MD at Edinburgh, and two years later, he was the younger of two physicians in practice at Louth, but by 1783, he had moved to Hull to join a fellow-1777 Edinburgh graduate, Alexander Bertram, as one of the three physicians at the temporary infirmary opened there in September 1782. A final example of professional mobility among medical practitioners can be seen in the career or Robert Davison, one of the élite band of British practitioners trained at Leiden, where he qualified in 1768. By 1779, he was in practice at Pontefract, where another physician and six surgeon-apothecaries were also established. In 1782, the senior physician at Leeds infirmary, William Hird, died at the age of fifty-eight, and a year later, his place was taken by Davison, then in his mid-thirties. No reason was given why the only physician at Aylesbury, Dr Shuttleworth, left Buckinghamshire in 1783 to go to America, although William Lee Perkins (MD, Aberdeen) in Kingston, Surrey, by 1783, had formerly been "in considerable practice in Boston in America, but returned to England about two years ago on account of the troubles in that country". On his return to England, he settled in Doncaster before moving south.

Physicians who came from substantial gentry families frequently returned to their home area, as in the case of John Matthews (MD, Oxon.), who in 1783 moved from Brompton Row, London, to Hereford. He had been the fourth physician at $\mathrm{St}$ George's Hospital, an appointment he had held since 1781, and in 1782, he was a candidate for the Fellowship of the Royal College of Physicians of London. Aged twenty-eight, he returned to his native county, where his family were substantial landowners; he employed John Wyatt and Humphry Repton in 1788-90 to create a house and landscape at Belmont, two miles outside Hereford city. Whatever medical duties Matthews may have performed, his other activities, cultural, philanthropic, and county, were considerable. He served as Colonel of the Herefordshire militia, and was always known by this title, and as MP for the county, as well as writing volumes of verse. ${ }^{11}$ At his death in 1826, Belmont was purchased by another practitioner, Dr James Prosser, whose grand-nephew unhappily employed A. W. Pugin to transform the original house, ${ }^{12}$ praised by a contemporary as "peculiarly worthy of attention" in 1797. ${ }^{13}$

Although medical centenarians were exceptional, Simmons noted two, aged 101 and 104 , for 1783 , but the longevity of some physicians must have made ambitious young practitioners despair. When John Baker, MD, died in March 1782, he was aged eighty-two, the only physician in Richmond, Surrey. His place was taken by a young Scots graduate, William Grieve (MD, Edinburgh, 1770), then in his mid-thirties, who

\footnotetext{
${ }^{10}$ Adrian Henstock (editor), The diary of Abigail Gawthern of Nottingham, 1751-1810, Nottingham, Thoroton Society, 1980, XXXIII.

$"$ H. M. Colvin, A biographical dictionary of British architects, 1600-1840, London, John Murray, 1978, p. 411 , and Dictionary of National Biography.

12 Peter Reid, Burke's and Saville's guide to country houses, London, Burke's Peerage, 1980, II, p. 5.

${ }^{13}$ Samuel Ireland, Picturesque views on the River Wye, London, R. Faulder, 1797, p. 47.
} 


\section{The medical practitioners of provincial England in 1783}

had been sole physician in Peebles, a member of the Edinburgh Medical Society who gained a Scottish Fellowship in 1782. Sometimes the death of an established physician made a community attractive to two younger practitioners, who presumably competed for his former patients. Thus in February 1781, when John Trotter, MD, died in Darlington, the only physician in an industrial, expanding town, he was replaced by two young practitioners, John Rotherham, junior (MD, Uppsala, 1775), from Newcastle upon Tyne, which had five physicians, including his own father, and also by John Horsley (MD, St Andrews, 1772) from Stockton, where one other physician practised. Occasionally, there was family influence in a change of practice, as for example, with the Johnstone family in the Midlands. James Johnstone, senior (MD, Edinburgh, 1750), was a practitioner at Kidderminster when his son, also James (MD, Edinburgh, 1773) died suddenly of typhus aged only twenty-nine at Worcester, where he was one of the infirmary's three physicians. James, senior, aged fifty-four but said to be "vigorous, active and sprightly", moved to Worcester in 1783, and remained there on the hospital staff until his death in 1802.14 His other son, Edward, was appointed as physician at Birmingham general hospital in the year he qualified, 1779.

A number of practitioners, however, died very young, possibly as a result of the hazards of the profession, and Simmons frequently noted such deaths. Several consumptive physicians left England for Portugal, as did their patients; Patrick Duguid Leslie (MD, Edinburgh, 1775, FRS), for example, died there in 1782 aged thirty-two of pulmonary consumption. In a period of almost uninterrupted warfare, Simmons listed military and naval surgeons who died on active service, for example, at the seige of Brimstone Hill, St Christopher, or who drowned at sea (one surgeon in the Glorieux at Jamaica, another at Portsmouth in the Royal George). A number of hospital surgeons also died young; Joseph Hollis of Nottingham was only thirty-two years old in May 1782, when his death was recorded by Simmons and noted by a local diarist in her journal. ${ }^{15}$

As an example of how businesslike eighteenth-century practitioners could be, the movement of physicians to fashionable Bath, with its gathering of wealthy hypochondriacs and genuine patients, has no contemporary equal, although Brighton, Buxton, Scarborough, and Weymouth each had a physician who resided temporarily at the watering-place during the height of the season. Bath was, however, exceptional not only in the size of its medical community in provincial England, but in the practitioners themselves, highly qualified men, many with professional publications to their credit, who had moved there to practise, in several cases leaving hospital appointments to do so. The general hospital at Bath, unique in being open to poor patients from any part of the kingdom who would benefit from hydrotherapy, was attended by three honorary physicians; in 1783, they were Henry Harrington, Daniel Lysons, and John Staker. There were also eleven other physicians practising in the town, of whom six had recently moved there for this purpose. Of these, John Morgan, MD, had formerly practised in Monmouth, and Caleb Hillier Parry (MD, Edinburgh, 1778) in Cirencester, a man of sufficient reputation to be named as an exemplary

\footnotetext{
14 William Henry McMenemy, A history of the Royal Worcester Infirmary, London, Press Alliances, 1947. pp. 115-118.

${ }^{15}$ Henstock, op. cit., note 10 above, p. 39.
} 


\section{Joan Lane}

former medical pupil of Warrington Academy. The other physicians at Bath had formerly held hospital posts, Francis Woodward (MD, Oxon.) at Bristol, John Smith (MD, Oxon., 1747) at the Radcliffe Infirmary, Oxford, and Matthew Dobson (MD, Edinburgh, 1756) at Liverpool.

Some practitioners lived at Bath for the sake of their own health; Francis Woodward, for example, had resigned from Bristol infirmary, where he served for twelve years (1757-69), because of ill health and moved to Bath, where he died in 1785 aged sixty-four. Such men, of course, could attend the occasional patient but not engage in full-time practice; thus, in November 1783, Woodward treated Sophy Thrale. ${ }^{16}$ Two other physicians, Thomas Manningham and Sir John Silvester, were also living in Bath in 1783, but were excluded from the town list. The most distinguished newcomer to Bath was perhaps Anthony Fothergill (MD, Edinburgh, 1763), who, soon after qualifying had settled in Northampton on the recommendation of his uncle, John. Apparently, he found difficulties in establishing himself in practice there, but early in 1765, he was appointed as one of the two physicians at the county hospital, where he remained until his resignation in 1781. ${ }^{17}$ On John Fothergill's death, he briefly went to London, but by 1783 , he had moved to Bath; his various changes of address in a short time caused Simmons several amendments to the original text. There were also two physicians at Bath of apparently European origins; Peter Renaudet had moved from Bristol Hot Wells since 1779, while John Berkenhout (MD, Edinburgh, 1764) left Bath in 1783 to practise in Winchester. In the 1779 Register, three of the town's physicians had been very elderly indeed, for two had qualified fifty years earlier (Philip de la Cour and Robert Gusthart), while a third practitioner, Dr Abel Moysey, was still treating the occasional patient up till his death there in $1780 .{ }^{18}$

It is difficult to tell from Simmons's Register how practitioners decided where they should practise; local knowledge, the hope of securing the patronage of distinguished patients, and the absence of any opposition must all have played a part. Although setting up in practice for a physician was not necessarily very costly, he needed a house or rooms where patients might consult him, a library, some form of transport, and the usual domestic servants. In the absence of an income, and anticipating patients who were slow to settle their bills, he also required some financial support for his daily living expenses. When Robert Darwin set up in practice in Shrewsbury late in 1786, his father, Erasmus, was able to boast that the young physician had "been concern'd for near fifty patients in the first six months", and he regarded this as "great encouragement" for his son. ${ }^{19}$ At the time Robert Darwin arrived in Shrewsbury, the county town had only three physicians, than whom he was considerably younger, but the distinction of his name in the midland counties was presumably a factor in his early success, apart from potential patients dissatisfied with their existing practitioner

\footnotetext{
${ }^{16}$ F. F. Waddy, A history of Northampton General Hospital, 1748-1948, Northampton and District Management Committee, 1974, pp. 20, 157.

17 R. W. Chapman (editor), The letters of Samuel Johnson, Oxford University Press, 1952, 3 vols., II, p. 106.

18 Ibid., p. 339.

19 Desmond King-Hele (editor), The letters of Erasmus Darwin, Cambridge University Press, 1981, p. 165.
} 
or unable to pay his bills, who would be willing to try a new and inexperienced physician.

A young man without Robert Darwin's advantages was James Currie, who had trained at Edinburgh but, at the age of twenty-four, took his degree at Glasgow because it was quicker, and therefore more economical, and he wished to seek a post. His medical training had been interrupted by an attack of rheumatic fever, but he was anxious to begin practice without asking his father, a cleric, for support. Unsuccessful in obtaining an army appointment in Jamaica, he wrote to a "near relation", William Currie (MD, Edinburgh, 1770), one of the three physicians at the Chester infirmary, and also to a university friend, Richard Worthington (MD, Edinburgh, 1778), who was in practice in Wrexham. Neither physician obviously wanted Currie as too close a rival, but, with William Currie's help, he established himself in Liverpool and by April 1781, he was elected as one of the physicians to the Liverpool dispensary. Five years later, he secured an appointment as physician to the infirmary, which he held until his health forced him to retire in 1805, when he went to live in Bath. ${ }^{20}$ Lack of professional opposition was an important factor in choosing where to practise, and some physicians wrote to friends in an area they thought might be suitable; thus, when John Fordyce wished to set up as a physician earlier in the century in Northamptonshire, a local divine wrote to him with sound advice, which Fordyce heeded and settled in Uppingham: "I believe that Wellingborough would be a promising situation for a physician to settle in; but ... I am told that that quarter is already possessed by Dr Godfrey, who has all the country business." 21

Although Simmons noted that certain practitioners had moved from one community to another in the years $1779-83$, others doing so, on whose mobility he did not comment, can be clearly traced through the Registers; thus five surgeon-apothecaries left Salisbury between 1779 and 1783 to practise in neighbouring towns. Other more sweeping changes can be detected by contrasting the two Registers, so that, for example, in the years between the two publications, one physician, Benjamin Charlesworth (MD, Edinburgh, 1769), two surgeons, Mr Lely and Mr Swan, senior, and the apothecary, Mr Broxholme Brown, all with posts at Lincoln Hospital, died, making possible four appointments for newcomers there.

Not only the physicians in Simmons's Register were professionally mobile, although because of their small numbers, well-recorded qualifications, social distinction, and public appointments, they were easier to trace than the surgeon-apothecaries at this period. However, Simmons also noted eighteen provincial surgeonapothecaries who changed their places of practice in 1783, their reasons for change often the same as the physicians'. Sometimes a surgeon-apothecary moved from a town where he was one of several men attending a community to a location where he was the sole practitioner; thus Mr Millwood, one of four surgeon-apothecaries in Buckingham in 1779, moved to Maidenhead where he was the only practitioner; and R. B. Batty transferred from Huddersfield, where two other surgeon-apothecaries

\footnotetext{
${ }^{20}$ William Wallace Currie (editor), Memoir of the life, writings and correspondence of James Currie. M.D., F.R.S., of Liverpool, 2 vols, London, 1831, I, pp. 3, 51-52, 55-58.

${ }^{21}$ Geoffrey F. Nuttall (editor), Calendar of the correspondence of Philip Doddridge, D.D., I701-.5I, Northampton, Northamptonshire Record Society, 1979, XXIX, p. 104.
} 


\section{Joan Lane}

practised, to Dewsbury, where he had no competition. Sometimes a move from a large to a small community was an obvious one; Thomas Jones left Leeds, where there were fourteen surgeon-apothecaries, for Bingley, where only one other man practised, while Thomas Paytherus moved from Gloucester to Ross-on-Wye, possibly because, although a Member of the Surgeons' Company, his chances of an infirmary appointment at Gloucester were reduced when the existing surgeon's son, S. V. Cheston, arrived in the city in 1783. Sometimes appointments were of the "general post" nature, explicable only in unknown personal circumstances; thus in 1783, John Armstrong left his two fellow surgeon-apothecaries in Brampton (Cumberland) for North Shields, while John Hudson began practice in Brampton having left Ireby (Cumberland). The establishing of provincial dispensaries at this period may also have encouraged mobility; thus Ludlow dispensary was founded in 1781, and in 1783, Richard Langslow left his rival surgeon-apothecary behind in Church Stretton to become one of six practitioners in Ludlow. In some cases, sons moved to join or leave a family practice; in 1783, Benjamin Chandler quitted Hertford, where he was one of five surgeon-apothecaries, to join his father's practice at Canterbury, presumably having gained experience at the expense of another man's patients, while Thomas Mantell, junior, set up in Dover, having formerly been in practice with his father in Chilham (Kent). It is not known whether such divisions were to consolidate or expand a branch surgery or the result of a personal rift. Practical advice on setting-up in the provinces was given by Erasmus Darwin; he suggested first that the young man should use all means to "get acquainted with people of all ranks", decorate his shop window attractively and appear in public at the farmers' ordinary on market days, at card assemblies, and at dances. Letters of introduction and "dressing to appear well; which money cannot be better laid out" would secure the young practitioner's success. Although this counsel was intended for a surgeon-apothecary intent on provincial practice, it was not entirely theoretical, for Darwin had had personal experience of the difficulty of establishing a practice as a young man of twenty-five. When he left Edinburgh, he set up as a physician in September 1756 in Nottingham, some twelve miles from his family home at Elston. As his practice did not thrive, he had moved by early 1757 to Lichfield, where the prosperous mercer, Luke Robinson, became his patient and the means of introducing Darwin to the midland scientific community. Darwin was again prepared to change his place of practice in the autumn of 1781; his second wife preferred her estate at Radbourne to Lichfield ${ }^{22}$ and, coincidentally, a prominent physician at Derby, only five miles away, William Butter (MD, Edinburgh, 1761), had just left the Midlands to live in London.

If a practitioner were unable to establish himself fairly quickly and lacked professional income, a move to another community was essential. One midlands diarist noted in her journal for 1773 how "Mr Ford (a cousin of Dr Ford who used to visit at Lambeth), and recommended by him to my father, came to Nottingham with a view of staying, found but little practice; he left in February."23

Some men made a series of moves in their career, each presumably intended to

\footnotetext{
22 King-Hele, op. cit., note 19 above, pp. 206, viii, xii.

${ }^{23}$ Henstock, op. cit., note 10 above, p. 28.
} 
improve their opportunities for prosperous practice. In 1779, John Blount was one of three surgeon-apothecaries at Bromyard, Herefordshire; by 1783, he had moved to Birmingham, where a new hospital had just opened, to be one of eleven surgeonapothecaries in the town. He remained there until 1791, but did not gain a hospital appointment, and by 1792, was in practice in Warwick. By 1797, he was in partnership with an old-established practitioner, and by 1808 , he had set up a private lunatic asylum in the borough, with eight inmates. ${ }^{24}$ Perhaps because of competition in the area, where there were several existing madhouses, he moved in the early nineteenth century to Great Wigston, Leicestershire, where he set up another asylum. By 1818, he had apparently moved back to Birmingham to practise. ${ }^{25}$

Other men moved because there was clearly too much competition in their area and only a limited number of patients; thus Joseph Cartledge (MD, Edinburgh, 1769), one of three physicians at Halifax in 1783, who also practised surgery and pharmacy for a livelihood, moved $2 \frac{1}{2}$ miles away to nearby Elland, where his only rival was a surgeonapothecary. Some men must have moved because they did not hold a hospital post, with its implications of status and seniority in the medical community, and their chances of doing so were poor. Thus in 1783, when Thomas Baker (MD, St Andrews, 1777), presumably in his late twenties, was not one of the four infirmary physicians at Norwich, he moved to Leighton Buzzard in Bedfordshire, where only one surgeonapothecary, Mr Stubbs, was in practice. Although many men of different occupations saw opportunities for their careers to flourish by going to London, some London medical practitioners saw openings in the provinces, so that, for example, in 1783, John Parson, MD, an assistant physician at the Finsbury dispensary at Clerkenwell, moved to Tavistock in Devon, where only a single surgeon-apothecary practised in a substantial community. Similarly, another young Scots graduate, Fotherby Pannel (MD, Edinburgh, 1775), moved from Northallerton to the county town of Buckingham, where the only medical attention was provided by four surgeon-apothecaries in 1783.

Opportunities for practice also occurred because older men retired or died. Thus in 1783, John Gould (MD, Edinburgh, 1764) left St Austell for Truro, where he replaced Dr Walcot, who had presumably retired, since Simmons did not list his name among the obituary notices. Other vacancies occurred because more senior men took hospital appointments, which, though unpaid posts, must have meant that they had less time to attend other patients, and so younger practitioners were able to join a community; in 1783, Charles Stapleton (MD, Leiden) moved from Manchester to Preston, where he replaced John Cowling, who had been appointed as one of the three physicians at Manchester infirmary. Generally, eighteenth-century practitioners did not retire while able to work; among the 363 physicians listed in 1783 only five were said to be retired, while two surgeons and two surgeon-apothecaries were also in this category. Death, however, provided professional career opportunities for practitioners, especially for those willing to move from one area to another.

Although Simmons noted that certain practitioners had moved from one community to another in the years 1779-83, others doing so on whose mobility he did not

${ }^{24}$ Warwick County Record Office [WCRO], QS 24/a/I/6, Minutes V.M.

${ }^{25}$ Wrightson's new triennial directory of Birmingham, Birmingham, R. Wrightson, 1818, p. 17. 
comment can clearly be traced in the Registers, for instance, the five surgeonapothecaries who left Salisbury during these four years to practise in neighbouring towns. Other more disastrous changes can be detected by comparing the two Registers; for example, the apothecary, two surgeons, and one physician at Lincoln hospital who all died in the years 1780-83. It is apparent, however, from the Registers, that the majority of medical practitioners remained in the same community where they had built up goodwill and had established premises and a clientele. Some families had almost dynastic medical influence over certain counties, with several members of different generations in practice (the Bryants in the West Country and the Wykes in the Welsh Marches), while some practitioners of 1783, such as the Bree, Langford, and Welchman families, had descendants in medical practice in the present century. A further network of relationships can be discerned through the handful of practitioners with distinctive medical middle names that were presumably from family origins, patronage, or a god-parent. Thus Bernard Snow, a surgeon-apothecary in Southam (Warwickshire) in the years 1776-1811, had Geary as his middle name, while Bernard Geary had practised in Warwick (c. 1753-90) until his death in $1798 .{ }^{26}$ In Sheffield, Charles Hawkesley Webb, who qualified after the 1779 Register as a surgeonapothecary, was presumably connected with an older practitioner of the same town, John Hawkesley.

Although in 1783, physicians were not in professional partnerships, there were exceptions when two members of the same family practised in a community, such as the Fenwicks at Morpeth or the two men of the Aery family and the two Dixons, all at Whitehaven. There were, however, a number of surgeon-apothecaries' partnerships listed by Simmons; the traditional fathers and sons, brothers, uncles, and nephews working together made up sixty-six two-man practices, as well as one, the Gaunts of Halesowen, consisting of a father and two sons. These family partnerships comprised 5.2 per cent of the civilian surgeon-apothecaries in the provinces at this period. A handful of such partnerships indicate a trend towards the junior practitioner's apparently having better qualifications than the older man, for example, Messrs Baker of Hoddesdon, Clowes of Wingham, Lowdell of Brighton, Travis and Wilkinson of Scarborough, all had junior partners who were members of the College of Surgeons while the older men were not. Apart from these family partnerships, there were, in addition, a further eighty-eight two-man practices where the partners' surnames were different, although some may well have been connected by marriage or by a former master-apprentice relationship. There was also one three-man practice, Holbrooke, Douglas and Thorpe of Loughborough, apparently established since the 1779 Register was published, and these partnerships formed 6.8 per cent of the provincial surgeon-apothecaries in practice in England in 1783, leaving eighty-eight per cent of practitioners working on their own.

The importance of a medical partnership may be judged by the fact that the partners were legally required to notify the general public when it was dissolved, exactly as other traders in a community informed their clients or customers. Thus, in the year of the Register a midlands newspaper carried an announcement:

${ }^{26}$ WCRO, DR 583/45 and /46; DR 447/2. 


\section{The medical practitioners of provincial England in 1783}

Partnership Dissolved

Whereas, on Monday the 14th of October, 1783, the Partnership between Messrs WALTON and BROWN, Surgeons and Apothecaries at Bedworth, in the County of Warwick, was dissolved by mutual Consent: All Persons who stand indebted to the said Copartnership are desired forthwith to pay their respective Debts to Mr William Court, at the Charity-School, in Bedworth aforesaid, who is authorized to receive the same: - And all Persons who have any Claims or Demands on the said Copartnership are desired to bring in their Accounts to the said William Court. ${ }^{27}$

Seven weeks later, the junior partner in this practice inserted the following notice, indistinguishable from advertisements by leading craftsmen (a saddler or cabinetmaker) or superior retailer (a tea merchant or milliner):

Richard Brown, Surgeon, Apothecary, and Midwife, begs Leave to acquaint his Friends and the Public in General, that he has taken and entered on a house near the White-Lion in Bedworth, where all Persons who please to favour him with their Commands may depend upon the strictest Assiduity and Attention. ${ }^{28}$

Among the 363 provincial physicians Simmons listed in 1783, there were five men described as "retired"; William Brownrigg (MD, Leiden, 1737) had "practised with considerable reputation" at Whitehaven but had retired "long ago" to Ormthwaite, his family seat, near Keswick, while Benjamin Pugh, MD, had retired to Badow from Chelmsford, where he had "practised many years with reputation, first as a Surgeon, and latterly as a Physician". At Ashford, Isaac Rutton, MB, had retired since the 1779 Register, while Moses Griffith, MD, lived in retirement at Colchester; the town of Reading had two former physicians living there, Anthony Addington and Thomas Adams. The information Simmons provided about physicians indicates more than their mere geographical distribution, although this in itself is interesting. Apart from cathedral cities, watering-places, towns with hospitals and dispensaries, physicians could also be found near royal residences (Windsor, Richmond, and Hampton Court) and aristocratic seats (Alnwick, Burghley, and Castle Howard).

Of the 1783 physicians, a total of seventy-three held civilian hospital appointments, in all cases honorary, while the eight dispensaries were also attended by local physicians (Carlisle, Stroud, Liverpool, Leicester, Newcastle upon Tyne, Bamborough, Ludlow, and Bristol). A small group of physicians also ran private lunatic asylums in the provinces, Nathaniel Cotton at St Albans, Thomas Arnold at Leicester, Francis Willis at Stamford, William Perfect at Malling, and John Beevor at Norwich, while at Newcastle upon Tyne, York, and Norwich local physicians were in attendance at public institutions for the insane. Simmons did not include madhouses run by surgeon-apothecaries or by non-medical proprietors at this period, since presumably practitioners who sought an institution for their patients preferred establishments run by other physicians to those, as at Henley-in-Arden (Warwicks.) or at Hook Norton (Oxon.), where surgeon-apothecaries were the proprietors. ${ }^{29}$

For three-quarters of all the English provincial physicians he listed, Simmons was able by 1783 to cite where they qualified, whether in Scotland, England, or Europe (see Table 2, p. 366).

Clearly, Edinburgh-trained men were by far the most commonly found practitioners, fairly evenly distributed across the provinces and prominent in hospitals (Table 4). However, preference for an Edinburgh graduate can be striking in certain

27 Jopson's Coventry Mercury, 3 November 1783.

28 Ibid., 22 December 1783.

29 William LI. Parry-Jones, The trade in lunacy, London, Routledge \& Kegan Paul, 1972, pp. 306-307. 


\section{Joan Lane}

circumstances, so that, for example, at Manchester infirmary all three physicians were Edinburgh men, at Birmingham hospital three of the four physicians were Edinburgh graduates, while both physicians at Lincoln hospital qualified at Edinburgh, although of two different generations, Robert Petrie in 1750 and Edmund Laycock in 1777. Clerics practising medicine were a diminishing group by this period, although William Walton of Upton (Hunts) and the Reverend Dr Watts of Market Harborough continued to do so. The two physicians licensed to practise by the Archbishop of Canterbury were noted disapprovingly by Simmons in his introduction to the Register as one of "that Prelate's" privileges.

Of the European universities, Leiden was the most popular for Englishmen at this period, but decreasingly so with the enhanced reputations of the Scottish medical schools; the later decades of the eighteenth century as a period of almost constant warfare for England may also have played a part in discouraging young men from travelling and being educated on the continent. By 1783 seven of the twenty-six Leiden graduates were very elderly indeed, five having qualified in the 1730s and therefore all in their seventies. These men were practising in Exeter (Thomas Glass, who graduated in 1731), in Liverpool (Walter Green, 1732, and John Kenion, 1739), in Carlisle (George Carlyle, 1736), and in Whitehaven (Richard Dixon, 1739). The graduation dates of seven Leiden men were not stated, but of the younger physicians a foreign training was clearly less favoured by the 1760 s, for of the nine dated Leiden graduates only one or two from each decade were practising, one each in Salisbury (a graduate of 1781), Bodmin (1778), Malton (1776), York (1775), Whitehaven (1772), Leeds (1768), Ashford (1765), Battle (1753), and Worcester (1751), the last of whom were presumably men past middle age by 1783 . The other foreign universities provided only eight English provincial physicians alive by 1783; the two men from Rheims were at Berwick and Bath, the Louvain graduates were at Leicester and Stafford hospitals, while the others were practising at Beverley (John Johnstone from St Omer), at York (Allen Swainston from Göttingen), at Bristol (Thomas Rigge from Padua), and at Darlington (John Rotherham, junior, from Uppsala).

TABLE 2: UNIVERSITIES AT WHICH ENGLISH PROVINCIAL PHYSICIANS QUALIFIED

$\begin{array}{cl}\text { Scotland } & \begin{array}{l}\text { Aberdeen } \\ \text { Edinburgh } \\ \text { Glasgow }\end{array} \\ & \text { St Andrews } \\ \text { England } & \text { Cambridge } \\ & \text { Oxford } \\ \text { Europe } & \text { Göttingen } \\ & \text { Leiden } \\ & \text { Louvain } \\ & \text { Padua } \\ & \text { Rheims } \\ & \text { St Omer } \\ & \text { Uppsala }\end{array}$
number of physicians

$\begin{array}{rr}15 & 5.5 \\ 128 & 46.8 \\ 7 & 2.6 \\ 24 & 8.8 \\ 34 & 12.4 \\ 31 & 11.3 \\ 1 & .4 \\ 26 & 9.5 \\ 2 & .8 \\ 1 & .4 \\ 2 & .8 \\ 1 & .4 \\ 1 & .4\end{array}$




\section{The medical practitioners of provincial England in 1783}

The actual date at which physicians graduated was the information least often recorded by Simmons, possibly because his correspondents did not know or could not ascertain this vital fact, so that qualifying dates are recorded for only 177 (forty-eight per cent) of all the English provincial physicians in 1783. The twenty-six oldest men, qualified for thirty years or more but still practising, comprised seven per cent of all the listed civilian physicians in the provinces; other graduation years after 1753 show a steady but unspectacular rate (Table 3). The year of the Register, 1783, is presumably under-represented but it is clear that many physicians survived and practised well into old age, presumably an obstacle to younger men seeking appointments. However, the group who qualified in the decade 1760-9 must have been aged between forty-five and thirty-four, while the men who graduated in the years 1770-9 were in the age-range thirty-five to twenty-four if their age at qualifying were twenty-one. Although some variation existed in individual careers, physicians for whose training substantial details survive support this estimate.

\begin{tabular}{|c|c|c|c|c|c|c|c|}
\hline years & number & years & number & years & number & years & number \\
\hline 1750 & 2 & 1760 & 0 & 1770 & 7 & 1780 & 5 \\
\hline 1751 & 4 & 1761 & 1 & 1771 & 6 & 1781 & 11 \\
\hline 1752 & 1 & 1762 & 1 & 1772 & 9 & 1782 & 10 \\
\hline 1753 & 4 & 1763 & 0 & 1773 & 3 & 1783 & 3 \\
\hline 1754 & 4 & 1764 & 5 & 1774 & 3 & & \\
\hline 1755 & 2 & 1765 & 5 & 1775 & 10 & & \\
\hline 1756 & 4 & 1766 & 5 & 1776 & 6 & & \\
\hline 1757 & 3 & 1767 & 2 & 1777 & 11 & & \\
\hline 1758 & 1 & 1768 & 6 & 1778 & 8 & & \\
\hline 1759 & 2 & 1769 & 5 & 1779 & 4 & & \\
\hline
\end{tabular}

The promotion of young men to hospital posts was sharply debated by the Select Committee on Medical Education of 1834, when nepotism and patronage were said to be rife and it was suspected that a man's connexions were more significant than his own talents in securing a post. ${ }^{30}$ Clearly, with far fewer hospitals and appointments in the 1780s, especially in the provinces, the problem was less obvious. However, in the years of Simmons's Registers there were certainly families holding hospital posts from one generation to another, for example, the Cams at Hereford, or the Parnels and the Swans at Lincoln. A network of marriage connexions in a provincial medical community can also be seen; thus at Nottingham the two Seawell sisters both married local surgeon-apothecaries named Basnet and Iliff. ${ }^{31}$ While the Birmingham surgeon, Edmund Hector, married the sister of a Kenilworth surgeon, Henry Power, ${ }^{32}$ his own sister, Ann Hector, was the wife of a Welwyn surgeon, Walter Hopper. ${ }^{33}$ Promoting a talented former apprentice to a hospital appointment was quite commonplace for surgeons, ensuring the master's methods and influence were continued and ambitious rivals kept at bay. At Newcastle upon Tyne in 1767, a surgeon's son, William Ingham,

30 PP 1834, op. cit., note 5 above, p. 98.

${ }^{31}$ Henstock, op. cit., note 10 above, pp. 46, 70.

32 WCRO, CR $611 / 749$.

${ }^{33}$ Philip B. Chatwin (editor), The records of King Edward's School, Birmingham, V, Oxford, Dugdale Society, 1963, XXV, p. 79. 


\section{Joan Lane}

was apprenticed at the age of fourteen to Richard Lambert, a surgeon of repute at the infirmary. When Ingham finished his apprenticeship and his London training, they became partners and the younger man replaced Lambert on his retirement from the infirmary in $1779 .{ }^{34}$

Of the seventy-three physicians who held hospital posts in the twenty-five provincial infirmaries of 1783 (for Hull had made appointments while Taunton was still building and Simmons had no names for the latter institution), a striking number were Edinburgh men, the majority of whom (nineteen) had qualified in 1770 or later:

\begin{tabular}{|c|c|c|}
\hline University & graduates in hospital posts & percentage \\
\hline Edinburgh & 31 & 42.5 \\
\hline Oxford & 14 & 19.2 \\
\hline Cambridge & 6 & 8.2 \\
\hline Leiden & 6 & 8.2 \\
\hline Glasgow & 3 & 4.2 \\
\hline St Andrews & 2 & 2.7 \\
\hline Louvain & 2 & 2.7 \\
\hline Göttingen & 1 & 1.4 \\
\hline not stated & 8 & 10.9 \\
\hline
\end{tabular}

Of these men, some were very newly qualified indeed; both physicians at Salisbury were 1782 graduates, while several hospitals appointed one very young physician with middle-aged men in senior posts, for example, at Northampton and Winchester. At Bath and Oxford hospitals, all the physicians appointed were Oxford graduates, while the occasional surgeon, such as Philip Gresley at the Worcester infirmary, had recently held military rank.

Since physicians primarily practised in cities, county towns, and other substantial communities but were only rarely found in smaller townships, many travelled to affluent distant patients. Erasmus Darwin's, for example, were widely scattered across the Midlands, obliging him to undertake long and time-consuming journeys in his specially fitted carriage. Physicians of less repute were also obliged to travel and to attend cases at inconvenient hours, especially when summoned by the wealthy or aristocratic patient. Thus in November 1782, when Lady Bagot went into labour at the Saracen's Head inn at Daventry (Northants.) while on a journey, she had the services of William Kerr of Northampton (MD, St Andrews, 1782). The baby, later to be the Bishop of Bath and Wells, was Lady Bagot's second son, and his father wrote cheerily to a friend, a midland landowner, of the event: "However awkward the Place I am happy to tell you my Wife was here this morning ab'six o'Clock safely delivered of a fine Boy, \& that she and her Child are both as well as possible. She was attended by Kerr of Northampton who always attends Mrs Chester." 35 Not all such visits were without incident, however, for a month later, Kerr was a victim of a highwayman when visiting a patient some thirteen miles distant from his practice:

${ }^{34}$ P. M. Horsley, Eighteenth-century Newcastle, Stockfield, Oriel Press, 1971, pp. 119-129.

3s WCRO, CR 136/B 1429-1436. 
We hear from Northampton, Dec, 2, that last Thursday evening between six and seven o'clock, as Dr Keir, of that town, was going to Daventry, to visit a patient, he was robbed by a single highwayman, about a mile and a half from that place. He behaved with great insolence; broke the glass of the chaise with his pistol, and took, besides the watch and money, everything the Doctor had in his pocket, even his letters and papers. ${ }^{36}$

In spite of the informative and factual style of the Register, there are occasional moments when the compiler expresses himself through the wording of the entries and lists. Simmons's annoyance can be sensed in the very few incomplete entries, so that at Oundle he noted the surgeon-apothecaries as Mr John Campion "and others", while at Patrington "Mr Elliott and another" were in practice. He occasionally added single items of information that were of medical relevance and presumably interested him. Thus we learn that a surgeon-apothecary from Cleobury Mortimer named Seager was one of the Shropshire coroners, but Simmons did not add the same information for William Clare of Devizes, whose family served in this office for Wiltshire for more than seventy years, as well as engaging in medical practice. ${ }^{37}$ In the 1783 Register, Simmons sometimes omitted interesting details that he had thought worthy of comment in 1779; thus at Lichfield in the first Register, Simmons noted that Richard Green owned a museum that was "well worthy the inspection of the curious" but did not make this entry in the 1783 edition against Green's name. Although Simmons did not indicate distinguished men in his lists unless they were physicians, it nevertheless gives the modern reader a strange sense of immediacy with the eighteenth century to see the names of "Mr Jenner" at Berkeley or of "Mr Crabb" at Aldburgh listed as practising. As well as personalities, Simmons also collected information, when possible, about the medical and other societies that would interest his readership. Thus, at Chester and Liverpool he described the Inoculation Societies; at Liverpool, Manchester, and Leeds, the Literary and Philosophical Societies, while the medical libraries at Liverpool and Leeds were worthy of comment, as was the Botanical Society recently established at Lichfield, even though it never had more than three members. ${ }^{38}$ The Medical Society founded at Colchester in 1774, the only provincial society so named, had three physicians and sixteen surgeon-apothecaries as members. Simmons also listed the Humane Societies at Liverpool and Leeds that had been established by 1783 based on the London model.

However, if the 1783 Register is to be considered as more than of mere antiquarian interest, an estimate of its accuracy and completeness as a basis for modern research is important, especially when set alongside other, unrelated contemporary record material. The medical practitioners of the county of Warwick provide a good yardstick for such an assessment; for 1783, Simmons listed fifty surgeon-apothecaries in practice in the county, excluding Birmingham. Of these fifty, a total of forty-five have been traced in other local records attending the poor, and four of the five physicians listed by Simmons are similarly recorded. ${ }^{39}$ There is no reason to think that Warwick-

\footnotetext{
${ }^{36}$ Coventry Mercury, 9 December 1782.

${ }^{37}$ R. F. Hunnisett (editor), Wiltshire Coroners' Bills, 1752-96, Devizes, Wiltshire Record Society, 1981, XXXVI, pp. xlviii-xlvix.

38 King-Hele, op. cit., note 19 above, p. 109.

${ }^{39}$ Joan Lane, 'The parish surgeon and his services to the poor, 1750-1800', Bull. Soc. soc. Hist. Med., 1981, no. 28
} 


\section{Joan Lane}

shire was more accurately listed by Simmons than other areas, but it is an indication of the Register's reliability when checked against other original material.

In spite of the Register's merits for the modern researcher, it has certain obvious defects. The alphabetical order is distinctly erratic, both for towns in the county lists and particularly for the main name index at the end of the volume, so that individual practitioners' names can easily be missed. Some are obviously mis-spellings as a result of printing errors or the handwriting of Simmons's local correspondents and his own unfamiliarity with place-names. As the range of male Christian names in the eighteenth century was a narrow one, a number of practitioners quite accidentally shared the same name, although clearly separate persons. The index occasionally fails to distinguish them, so that, for example, there were two men named John Anderson, one a physician at Kingston, Surrey, and the other a surgeon to the Newcastle upon Tyne dispensary, but the indexer has put all their entries as if for one man. The greatest omission, however, especially for the modern reader, is the large number of practitioners, notably the surgeon-apothecaries, whose Christian names Simmons did not include, even occasionally when he knew them. Thus, for example, the two Parnels, father and son, surgeons at Lincoln infirmary, can be identified as Paul Parnel, senior and junior, not from the county list but from their inclusion in the College of Surgeons' members. Other contemporary record material can be used, if the researcher is fortunate, to supply the missing Christian names, rather than a laborious search of parish registers, a fruitless task if the man practised away from his home area. National records, such as militia lists of the period, giving the names, places, and often the occupations of men, aged eighteen to forty-five, liable for military service, may make exact identification possible. Medical practitioners, unless also clerics, were obliged to do militia service. In Northamptonshire, for instance, the militia list for 1777 reveals the Christian names of seventeen practitioners of the fortysix in the county given by Simmons only as, for example, Mr Hodges (who was William) of Towcester, or Mr Swinfen (Edward) of Long Buckby. For the county town, the militia list recorded that Dr Anthony Fothergill lived in the East Ward, while Joseph Harding, a surgeon at the infirmary, was in Chequer Ward. ${ }^{40}$ National or local trade directories for the 1780s are unfortunately fairly rare, but one for 1791 gives further Christian names for some of Simmons's practitioners, so that Mr Deacle of Banbury (Thomas), Mr Nash of Bromsgrove (Thomas), and Mr Jones of Wolverhampton (Joseph) can all be identified more fully. Although apprenticeship records for surgeon-apothecaries are the most reliable and detailed sources when they survive, by the later eighteenth century they were kept far less systematically than in earlier decades, but they can still be used to supplement Simmons's names. Thus, in Southwell, Nottinghamshire, Messrs Falkner and Smith were listed by Simmons in both the 1779 and the 1783 Registers; the former partner can be identified as Thomas Faulkner, who took an apprentice, Henry Bower, in 1764 for seven years. At Oxford, Simmons's Mr Clarson, listed in both Registers, appears, by his uncommon name, to be Henry Clarson, apprenticed to a Banbury surgeon-apothecary, William Hayward,

\footnotetext{
${ }^{40}$ Victor A. Hatley (editor), Northamptonshire militia lists, 1777, Kettering, Northamptonshire Record Society, 1973, XXV, pp. 184, 183.
} 
in 1765 , also for seven years. ${ }^{41}$ Other eighteenth-century material can occasionally give additional, personal details to the bare facts provided by Simmons; he noted, for example, the death on 6 June 1783, of Thomas Lawrence, formerly President of the College of Physicians, at Canterbury. Fortunately, Lawrence had been Samuel Johnson's physician since 1755, and, as Johnson enjoyed poor health almost as much as correspondence, he wrote of Lawrence's death confirming Simmons's notice, that "poor dear Dr Lawrence is gone to die at Canterbury", with a description of his symptoms. ${ }^{42}$ It is, however, undeniably reassuring that so much of Simmons's detail, when checked against other contemporary material that has randomly survived, is found to be reliable and useful for modern research.

The rather unsystematic collection of medical names, dates, and places that Simmons made two hundred years ago has suffered from neglect by modern historians. Yet in a period before trade and county directories were commonplace, his was exceptional in listing the members of one particular occupation, on a geographical basis, with information about medical institutions, professional bodies, and individuals. The Law List was not to appear until 1839 and Crockford's Clerical Directory until 1870. One of the great merits of Simmons's Register was that, as a practitioner himself, he understood the different categories of medical status and qualifications, unlike the compiler of a commercial or area directory, who often confused the various branches of medical practice and awarded or denied qualifications with equal ease. Simmons's final pages of errata and amendments, "received since the Appendix was printed" he added waspishly, suggest that he was a punctilious, careful, and conscientious man, concerned not to be seen at fault, aware that his compilation was worth nothing if inaccurate. In such a detailed work, only his entry for Bath practitioners seems to have been disastrously wrong, and he added a footnote to the effect that "Our list of the Physicians and Surgeons of this Hospital, page 105, is erroneous", followed by an amended version. While later, official medical registers were not to appear until the middle of the nineteenth century, Simmons's work in its third edition of 1783 remains typical of his time, highly individualistic, unconcerned for bureaucracy, keenly aware of social and professional status but anxious to regularize the practice of contemporary medicine by recognising the qualified and excluding the quack.

\section{ACKNOWLEDGEMENTS}

I should like to thank the following archivists and librarians for helpful suggestions about sources and for answering particular queries well beyond the call of duty: Miss M. E. Williams at Bristol, Miss S. Hubbard at Hereford, Dr R. Bearman at Stratford-upon-Avon, Mr R. J. Chamberlain-Brothers and Mrs C. Woodland at Warwick, Miss C. Penney at the University of Birmingham Library, Mr E. Cornelius at the Royal College of Surgeons of England, Mr R. Price at the Wellcome Institute, and Mr D. Whitehead for advice about architecture.

41 PRO, I.R.1/55.

${ }^{42}$ Chapman, op. cit., note 17 above, II, p. 500. 